\title{
Dealing with Purposes in Intercultural Communication: Some Methodological Considerations
}

\author{
Christiane Nord \\ Magdeburg / Germany \\ Christiane.Nord@Fachkommunikation.FH-Magdeburg.DE
}

\section{Preliminary remarks}

According to functional theories of translation, translating is regarded as a "purposeful activity" (cf. Nord, 1997). This means that a translation process does not "happen" by itself. It is a communicative action carried out by an expert in intercultural communication (the translator), playing the role of text producer and aiming at some communicative purpose. Communicative purposes are directed at other people who are playing the role of receivers. Communication takes place through a medium and in situations that are limited in time and place. Each specific situation determines what and how people communicate, and it is changed by people communicating. Situations are not universal but are embedded in a cultural habitat, which in turn conditions the situation.

In translation, the translator deals with a source text produced under source-culture conditions for a source-culture audience. What is said and how it is said was determined by the author's communicative purposes and his or her assessment of the situation for which it was intended. The translation, however, will be used in a different situation deterinined by target-culture conditions. It is different with regard to time and place (except in simultaneous interpreting), sometimes with regard to medium (the translation of Saint Paul's letter to the Corinthians is published in a book called "The New Testament"), and definitely with regard to the addressed audience (e.g., their general and cultural knowledge, there sociocultural background, their value systems and world view).

If the functionality of a text is determined by these extratextual or pragmatic factors, it is obvious that in order to make a source-culture text work in a target-culture situation the translator's activity involves more than just a "replacement of textual material in one 
language (SL) by equivalent material in another language", as Catford put it more than thirty-five years ago (Catford, 1965:20). The meaning or function of a text is not something inherent in the linguistic signs; it cannot simply be extracted by anyone who knows the code. A text ist made meaningful by its receiver and for its receiver. Different receivers (or even the same receiver at different times) find different meanings in the same lingusitic aterial offered by the text. We might even say that a "text" is as many texts as there are receivers of it.

Somebody who commissions a translation and is willing to pay some (although generally too little) money for it, usually has some purpose in mind for which the target text is needed. Therefore, the translator - like any other text producer - analyses the pragmatics of the (prospective) target situation before deciding on what to say (i.e. how to rearrange the information given in the source) and how to say it (i.e. what linguistic or even non-linguistic devices to use in order to make the text fit for the client's purpose).

Every translation process is guided by the communicative purposes the target text is supposed to achieve in the target culture. This is a very simple principle. But how can we deal with these purposes? How do we define a communicative purpose? Can we find categories or types of purpose? What are the conditions for the transfer of purposes across a linguistic and cultural barrier? In the following sections, I will try to answer these questions. After explaining my concept of communicative purposes and functions (section 1), I will propose a four-function model to be used in the translation class (section 2). We will see how the basic functions (and their respective sub-functions work in intra and intercultural communication and what consequences can be derived from the model for translation practice and training (section 3). To illustrate the model, I will use a few examples taken from a new German translation of the New Testament (Berger \& Nord, 1999), which will be contrasted with the classical English King James Version and the Spanish translation by Nácar \& Colunga (1975).

\section{Purposes and Functions in Communication}

The basic theory behind modern functionalist approaches to translation is Skopostheorie (Vermeer, 1978). Skopos is a Greek word for "purpose". In the theory, skopos usually refers to the communicative purpose of the translational action. To say that an action has a purpose is to presuppose the existence of free will and a choice between at least two possible forms of behaviour. This means that if in a given translation assignment there are two (or more) possible ways of translating the source text (or any of its segments), the translator has to make a choice. The main criterion for this choice is the communicative purpose the client wants to achieve with the translation (e.g., sell a product, convince the audience of certain ideas, inform or instruct the readers how to use a particular machine, explain the use of a new technical term, share an aesthetic or emotional experience).

If it is really the receiver who decides on the functionality of a text, there is no garantee that a text really achieves the communicative purpose for which it is produced. Therefore, 
I propose a basic distinction between purpose or intention, on the one hand, and function, on the other. Purpose or intention is defined from the viewpoint of the sender, whereas function is seen from the receivers perspective. In an ideal situation, the sender's intention will find its aim, in which case intention and function would be congruent. But very often, especially where source and target cultures are separated by a large cultural distance, it is actually impossible that the sender's intention becomes the text function for the target readership.

\section{Example 1: 1 Cor 6,9}

"Know ye not that the unrighteous shall not inherit the kindom of God? Be not deceived: neither fornicators, nor idolaters, nor adulterers, nor effeminate, nor abusers of themselves with mankind, nor thieves, nor covetous, nor drunkards, nor revilers, nor extortioners, shall inherit the kingdom of God" (KJV).

"¿No sabéis que los injustos no poseerán el reino de Dios? No os engañéis; ni los fornicarios, ni los idólatras, ni los adúlteros, ni los afeminados, ni los sodomitas, ni los ladrones, ni los avaros, ni los ebrios, ni los maldicientes, ni los rapaces poseerán el reino de Dios" (Nácar \& Colunga, 1975).

St. Paul's intention to make his addressees refrain from what he calls porneia (which beside prostitution and sodomy includes also mixed marriages of Christians or Jews with gentiles, as opposed to the modern usage of the word fornication, cf. DCE, 1978, which refers to "sexual relations outside marriage") would not really find its aim in a Christian community today. Therefore, the function this text can have for modern readers is more or less that of a historical document informing them about a situation that is completely different from their own. And even this function is only feasible if the translation clarifies what is meant by fornication or fornicators in St. Paul's cultural situation.

We observe that merely on the grounds of cultural and temporal distance, a text representing St. Paul's appellative purpose will most probably have a mere informative function for a modern readership. If a translator (or commissioner) wanted to be "faithful" to the author's appellative intention, they would have to think of other ways to appeal to the audience's sense of what is right or wrong in sexual relations.

\section{The Four-Function Model}

\subsection{Theoretical points of departure}

Various models of text function could serve as points of departure for translator training. The model proposed here has the advantage of being simple enough to be used in the translation class and of having a clear focus on translation. It draws on the combination of two previous models: Karl Bühler's organon model (1934), and Roman Jakobson's model of language functions (1960). 
In his book Theory of Language, the German psychologist Karl Bühler regards the linguistic sign as a "tool" (in Greek: organon) which can be analysed on the grounds of its relationship with the main factors in communication, as depicted in his famous triangle:

OBJECT OF REFERENCE

(= referential function)

\section{SYMBOL}

\section{SIGN}

\section{SYMPTOM STIMULUS}

SENDER

(= expressive function)

RECEIVER

(= appellative function)

In Bühler's organon model, the three basic functions of language are the referential function, where the linguistic sign is a symbol of the object of reference, the expressive function, where the linguistic sign is a symptom of the sender's state of mind, and the appellative function, where the linguistic sign serves as a stimulus intended to move the receiver into some kind of attitude or action. These three basic functions are also present in Jakobson's model. In addition, however, Jakobson proposes a fourth basic function which seems to be lacking in Bühler's model: the phatic function, which refers to the communicative relationship between the sender and the receiver.

We will therefore complete Bühler's triangular model adding Jakobson's phatic function as a relationship between the linguistic sign, on the one hand, and the sender-receiver connection, on the other.

\section{OBJECT OF REFERENCE}

(= referential function)

SYMBOL

\section{SIGN}

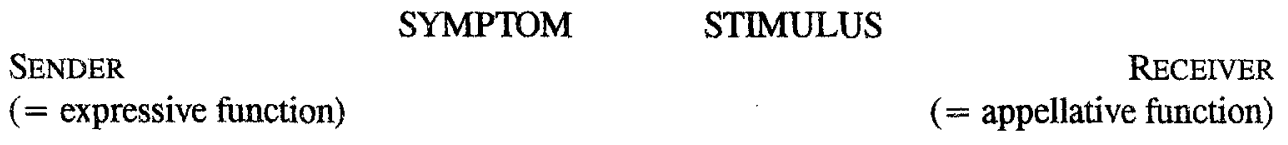

RELATIONSHIP SENDER-RECEIVER

(= phatic function) 
We will now define and describe these functions and some of their sub-functions, focussing on the way they work in communicative settings both within and across cultures.

\subsection{The Referential Function}

The referential function of an utterance involves reference to the objects and phenomena of the world or of a particular world, perhaps a fictional one. If the referent is a product unknown to the receiver, the text may describe its technical properties (= descriptive subfunction); if the referent is a language or a specific use of language, the sub-function may be metalinguistic; if the referent is the correct way of handling a washing machine, the subfunction may be called directive or instructive, and so on.

\begin{tabular}{|l|l|}
\hline BASIC FUNCTION & SUB-FUNCTION \\
\hline Referential function & description \\
\hline & \\
\hline & metalanguage \\
\hline & instruction \\
\hline & information \\
\hline
\end{tabular}

Table 1: Referential function and some sub-functions

To carry out the referential function, the receiver must be able to coordinate the message given in the text with the previous knowledge they have about the particular object in question. If the amount of new information is too large, the receiver will fail to understand the message; if there is too little new information, the receiver will be bored and may stop reading or listening altogether. Therefore, senders of referential utterances usually try to establish the appropriate balance between presupposed and new information.

Example 2: Lu. 6,17;20

And he came down with them [from the mountain] and stood in the plain, and the company of his disciples, and a great multitude of people... And he lifted up his eyes on his disciples and said... (KJV).

Bajando con ellos del monte, se detuvo en un rellano, y con Él la numerosa muchedumbre de sus discípulos y una gran multitud del pueblo... Él, levantando los ojos sobre sus discípulos, decía... (Nácar/Colunga, 1975).

Jesus setzte sich, sah seine ... Jünger an und sagte... (Berger/Nord, 1999: Jesus sat down. looked at his disciples... and said...).

In the source sulture, teachers used to be seated while they were teaching. He lifted up his eyes on his disciples indicates that Jesus is seated and starts teaching, while his disciples are standing around him. The author assumes this habit to be known by his addressees, therefore he need not make it explicit. Obviously, the translators of the King James Version (like so many other translators) did not bother much about coherence, otherwise they would 
not have translated [he] stood in the plain -why would Jesus lift up his eyes when he was standing? The Greek verb used in the original does not specify the body movement, like detenerse in Spanish. Spanish readers might nevertheless find it difficult to imagine Jesus seated. Berger/Nord, 1999 provide the readers with the information they need to visualize a coherent scene.

\subsection{The Expressive Function}

The expressive function refers to the sender's attitutde toward the objects and phenomena of the wordl. It may be subdivided according to what is expresed. If the sender expresses individual feelings or emotions, we may speak of an emotive sub-function; if what is expressed is an evaluation, the sub-function will be evaluative. Another sub-function might be irony.

\begin{tabular}{|l|l|}
\hline BASIC FUNCTION & SUB-FUNCTION \\
\hline & emotion \\
Referential function & \\
\hline & evaluation \\
\hline & irony \\
\hline & $\ldots$ \\
\hline
\end{tabular}

Table 2: Expressive function and some sub-functions

The expressive function is sender-oriented. If it is verbalized explicitly (e.g., by means of evaluative or emotive adjectives, as in: Cats are horrible!), the readers will understand it even when they disagree. But if the evaluation is given implicitly (like in: $A$ cat was sitting on the doorstep!), it may be difficult to grasp for readers who do not know on which value system the utterance is based (is a cat on the doorstep a good or a bad thing?). Many qualities have different connotations in two different cultures. Sometimes, a translator has to explicitate an implicit evaluation in order to avoid misinterpretations in the target culture.

Example 3: In 1,1-5: Darkness and the Light

In the beginning was the Word, and the Word was with God, and the Word was God. ...In him was life and the life was the light of men. And the light shineth in darkness; and the darkness comprehended it not (KJV).

Al principio era el Verbo, y el Verbo estaba en Dios, y el Verbo era Dios. ... En Él estaba la vida, y la vida era la luz de los hombres. La luz luce en las tinieblas, pero las tinieblas no la acogieron (Nácar/Colunga', 1975).

En el principio existía el Verbo, y el Verbo estaba con Dios, y el Verbo era Dios. En él está la vida, y la vida es la luz de los hombres; la luz luce en las tinieblas y las tinieblas no la sofocaron (Lamadrid et al., 1964).

Zuerst war das Wort da, Gott nahe und von Gottes Art. Es war am Anfang bei Gott. ... In ihm war das Leben, und das Leben ist Licht für die Menschen. Das Licht macht die Finsternis hell, und die Finsternis hat das Licht nicht verschluckt (Berger/Nord, 1999: At first, the Word was 
there, it was next to God and of God's kind. In the beginning it was with God. ... In it was life, and life is light for the humans. The light lightens the darkness, and the darkness has not swallowed the light).

Verse 5 offers two possible interpretations. Until today, theological scholars have not agreed on one of them. Both are evaluative, one is metaphorical (darkness [ = the world] did not understand or accept the role of the light $[=$ Jesus $I$ ) and the other one takes the Greek verb literally (the light was so strong that darkness could not overcome it, as in Lamadrid et al., 1964). The metaphorical meaning is rather pessimistic (and thus, modern!), whereas the literal meaning expresses the confidence of being victorious in the end. Berger/Nord, 1999 opted for the literal and positive meaning because (a) biblical language usually tends to be more concrete than what we are accustomed to; and (b) if you want to attract people to your cause you would not start telling them that it is not worth the effort in the first place.

\subsection{The Appellative Function}

The appellative function is directed at the receivers' sensitivity or disposition to act and aims at inducing the audience to respond in a particular way. If we want to illustrate a hypothesis by an example, we appeal to the readr's previous experience or knowledge; the intended reaction would be recognition of something known. If we want to persuade someone to do something or to share a particular viewpoint, we appeal to their sensitivity, their secret desires. If we want to make someone buy a particular product, we appeal to their real or imagined needs, describing those qualities of the product that are presumed to have positive values in the receivers' value system. If we want to make a person do something or refrain from doing something, we utter a command.

\begin{tabular}{|l|l|}
\hline BASIC FUNCTION & SUB-FUNCTION \\
\hline & illustration \\
\hline & \\
\hline Appelative function & persuasion \\
\hline & command \\
\hline & $\ldots$ \\
\hline
\end{tabular}

Table 3: Appellative function and some sub-functions

In the following example, Jesus appeals to the disciples' experience in order to illustrate his point that their Christian way of living must set a "shining" example to non-Christians.

Example 4: Mt. 5,14-15

Ye are the light of the world. A city that is set on a hill cannot be hid. Neither do men light a candle and put it under a bushel, but on a candlestick; and it giveth light unto all that are in the house (KJV).

No one lights a lamp and puts it under a bowl; instead he puts it on the lampstand, where it gives light for everyone in the house (GNB, 1976). 
Vosotros sois la luz del mundo. No puede ocuitarse ciudad asentada sobre un monte, ni se enciende una lámpara y se la pone bajo el celemín, sino sobre el candelero, para que alumbre a cuantos hay en la casa (Nácar/Colunga, 1975).

Und wer ein Licht anzündet, wird keinen Topf darüber stülpen, sondern es auf den Leuchter stellen, damit es allen im Haus hellen Schein gibt (Berger/Nord, 1999: Somebody who lights a lamp will not put a pot over it but place it on a lampstand to make it give light to everyone in the house).

The first example (the city on the hill) is rather general and will work with any reader who knows the difference between hills and plains. The second example cannot achieve its appellative function if the reader does not know what a bushel (or a celemin) is and what it looks like. The dictionary tells us that bushel is a "biblical" word referring to "a measure, esp. of grain; about 36.5 litres" (cf. DCE, 1978), but since the utterance is not meant to offer information about a culture where bushels obviously belonged to the normai equipment of a household, this definition is not very helpful. Therefore, the Good News Bible replaces the bushel by a $b o w l$, which makes the appellative function perfectly clear. Berger/Nord, 1999 add a tiny detail: If we want to hide a lamp under a pot or a bowl, we would rather put the receptacle over the lamp instead of placing the lamp under the receptacle (which has to be lifted and turned around anyway!).

\subsection{The Phatic Function}

The phatic function aims at establishing, maintaining or ending contact between sender and receiver and at defining the social role relationship holding between them (e.g., by the forms of address used or by conventional opening and closing formulas in letters or at the beginning or end of a lecture).

\begin{tabular}{|c|c|}
\hline BASIC FUNCTION & SUB-FUNCTION \\
\hline Phatic function & small-talk \\
\hline & salutation \\
\hline & politeness \\
\hline
\end{tabular}

Table 4: Phatic function and some sub-functions

Example 5: Phil. 1,1-2

Paul and Timotheus ... to all the saints in Christ Jesus which are at Philippi, with the bishops and deacons. Grace be onto you, and peace from God our Father, and from the Lord Jesus Christ (KJV).

Pablo y Timoteo ... a todos los santos en Cristo Jesús que están en Filipos con los obispos y diácoros: la gracia y la paz de parte de Dios, nuestro Padre, y deí Señor Jesucristo sea con vosotros (Nácar/Colunga, 1975). 
Paulus und Timotheus ... schreiben diesen Brief an alle Christen in Philippi, auch an alle, die dort Aufsicht führen und andere Dienste leisten. Von Gott unserem Vater, und vom Herrn Jesus Christus geben wir Gnade und Heil an euch weiter (Berger/Nord, 1999: Paul and Timotheus ... are writing this letter to all Christians at Philippi, and to all those who are in charge and who are doing service there. We are passing on to you the mercy and salvation provided by God, our Father, and our Lord Jesus Christ).

Example 5 shows a salutation which is typical of St. Paul's letters. He addresses the members of the Christian community as "saints in Christ Jesus", which means Christians. Verse 2 illustrates the culture-specific concept of the Apostle's authority to literally pass God's mercy on to others, which is no longer conveyed by the formulaic "Grace be onto you ... from God" or "la gracia y la paz de parte de Dios ... sea con vosotros". As far as forms of address are concerned, Spanish and German translators have to choose between the formal third person Sie/usted(es) and the informal second person (singular: dultú; plural: ihr/vosotros). In Bible translation, it has become conventional to use the informal forms of address, although this leads to strange ways of behaviour in certain situations.

\section{Dealing with Purposes and Functions in Intercultural Communication}

In the following section, we will look at what happens to the four basic functions in intercultural communication.

As we have seen, the referential function works on the basis of the information explicitly verbalized in the text plus the information which is not verbalized because it is assumed to be known to the addressed audience. In face-to-face communication, there may also be "situational indicators" compensating for any lack of previous knowledge. For example, there is no need to mention the conditions of time and space or the participants if they are evident to everybody present in the communicative interaction.

In intercultural communication, the referential intention of the source-text sender can be interpreted correctly as referential function by the target-text receiver under one of the following conditions:

if the textual information is sufficiently explicit,

if the object the source-text sender refers to is sufficiently familiar to the target-text receiver,

if the source-text sender and the target-text receiver share a sufficient amount of knowledge about the object in question, or if situational indicators compensate for information deficits.

If these conditions are not met, the translator has two basic options: 
either to make the ST sender's referential intention work as a meta-referential function for the TT receiver by giving additional information about the ST situation in a metatext (e.g., footnote, glossary, foreword);

or to make the ST sender's referential intention work for the target audience, giving additional information in the text (= expansion) or making the implicit information of the source text (presuppositions) explicit.

If it is explicit, the expressive function works on the basis of evaluative or emotive verbal or nonverbal elements. If it is implicit, it works on the ground of the value system and perspective shared by sender and receiver. In intercultural communication, the source-text sender's expressive intention can be interpreted correctly as expressive function by the target-text receiver under one of the following conditions:

if the expressive source-text utterances are explicit, or

if implicitly expressive source-text utterances refer to values shared by the source and the target culture.

If this is not the case, the translator again has to choose between two strategies:

either to make the ST sender's expressive intention work as a meta-expressive function for the target audience, which actually means turning it into a referential function by informing about or explaining the source text's expressivity in metatexts like footnotes or a foreword,

or to make the ST sender's expressive intention work for the target audience by making implicit evaluations explicit or by adapting the expressivity markers to target-culture patterns.

The appellative function works on the basis of common experience, sensitivity, world and cultural knowledge, emotions, values etc. shared by sender and receiver. The receiver must be able and willing to cooperate to make the appellative function work. In intercultural communication, the source-text sender's appellative intention can be interpreted correctly as appellative function by the target-text receiver

if the receivers in the source and the target culture share the experience, sensitivity etc. to which the source-text sender appeals.

If this is not the case, the translator may choose between three options, two of which involve a change of function:

either to make the ST sender's appellative intention work as a meta-appellative function for the target audience by means of explanations or comments in a metatext (which may 
amount to something like explaining why a joke is funny, but in certain situations this is what the client wants the translator to do..).,

- or to make the ST sender's direct appellativity work as indirect appellativity by drawing the target-culture audience's attention to the analogies between their own situation and the one described in the text,

- or to make the ST sender's appellative intention work as appellative function for the target audience by adapting it to target-culture functionality conditions or by replacing source-culture appellative elements with target-culture appellative elements.

The phatic function works on the basis of shared conventions. In face-to-face communication, "situational indicators" may compensate for unconventional behaviour if the situation clearly points to a phatic intention of one of the participants. In intercultural communication, the phatic intention verbalized in the source text can be interpreted correctly as phatic function by the target audience under the following conditions:

if the conventions of phatic communication are identical or similar in the source and the target culture, or

if the phatic intention is clearly indicated by situational clues.

If these conditions are not met, the translator may decide

either to change the phatic into a meta-phatic (= referential) function e.g. by informing about the phatic markers present in the source text, or to make the phatic intention work as phatic function for the target audience by replacing source-culture conventional behaviour patterns with target-culture behaviour patterns.

Analysing the conditions of functionality in intercultural communication we find that the translator's two basic options correspond to the dichotomies known in translation theory since the days of Cicero. The following table shows some of them. Type A refers to the "retrospective" or "source-oriented" strategy of keeping close to the source text, thus inevitably changing the function intended by the source-text author; Type B refers to the "prospective" or "target-oriented" strategy of adapting the target text to target-culture conditions in order to make the source-text author's intention or purpose work for the target audience (cf. Nord, 1997: 4ff).

Author

Cicero (106-43 B.C).: De

optimo genere oratorum

St. Jerome (348-420): Letter

to Pamachius
Type A

"[traducere] ut interpres" (translate like a translator) "verbum e verbo [exprimere]" (render word for word)
Type B

"[traducere] ut orator" (translate like a rhetorician) "sensum de sensu exprimere" (express sense for sense) 
Martin Luther (1483-1546):

Circular Letter on

Translation, 1530

John Dryden (1631-1700):

Preface to Ovid's Epistle,

1680

Friedrich Schleiermacher

(1768-1834): On the different

methods of Translating, 1813

Eugene A. Nida (1964)

Juliane House (1977)

Christiane Nord (1989) "translate" (reproduce the structures and the wording of the source text)

"metaphrase" (word for word or line for line)

"taking the reader to the [original] text" ( = "Verfremdung", exotization)

"formal equivalence"

(focussing on the source-text surface structures)

"overt translation" (for texts that are bound to a historical situation or author) "documentary transiation" (subdivided into word-forword, literal, philological and exoticizing translation forms, according to the purpose of the translation)
"Germanize" (i.e. adjust the text to the vernacular of the [German] target culture) "paraphrase" (sense for sense)

"taking the text to the reader"

"dynamic/functional
equivalence" (focussing on
the purpose of the source-
text author)
"covert translation" (for
texts used in everyday
communication)
"instrumental transiation"
(subdivided into equifunc-
tional, heterofunctional and
homologous translation
forms, according to the
purpose of the translation)

Table 5: Basic translation types

Although the definitions of type A and type B translations vary from one author to another, it is obvious that this "either-or" is typical of any translation process. Being a target-language text received under target-culture conditions, a translation cannot be "faithful" to the linguistic surface structures of the source text and preserve the author's intention at the same time. What matters, though, is the criterion determining the translator's decision. For example: Cicero related the choice between type A and type B renderings to the role of the translating person ("translator" vs. "rhetorician"), for St. Jerome it depended on the text type (Holy Scriptures vs. non-biblical literature). Luther already used a functional criterion ("exact interpretation" vs. "comprehensibility").

In certain cases and within the boundaries of a particular culture, we might speak of "conventional" relationships between text type and translation type. An operating instruction, for example, will normally require a type B translation, whereas a marriage certificate is usually rendered according to type A. In general terms, however, there is no rule specifying such a relationship. Like other conventions, translational conventions are arbitrary, culture-specific and may change when they are no longer in keeping with a changing society. Therefore, trainee translators should be made aware of the fact that there is usually more than one way to translate a particular source text. In order to make a decision, they have to analyse not only the source text but also the translation brief which (explicitly or -more often - implicitly) defines the communicative situation for which the target text is needed. 


\section{The Vision of the New Jerusalem as a Case in Point}

Except for purely phatic expressions or utterances, texts are rarely monofunctional. As a rule we find hierarchies of purposes that can be identified by analysing verbal or non-verbal function markers. To illustrate this last point, let us take a look at the "New Jerusalem" as described by St. John the Divine in the Revelation.

Example 6: Rev. 21,10;18-21

The wall was made of jasper, and the city itself was made of pure gold, as clear as glass. The foundation-stones of the city wall were adorned with all kinds of precious stones. The first foundation-stone was jasper, the second sapphire, the third agate, the fourth emerald, the fifth onyx, the sixth carnelian, the seventh yellow quartz, the eighth beryl, the ninth topaz, the tenth chalcedony, the eleventh turquoise, the twelfth amethyst. The twelve gates were twelve pearls; each gate was made from a single pearl. The street of the city was of pure gold, transparent as glass (GNB, 1976).

Su muro era de jaspe, y la ciudad oro puro, semejante al vidrio puro; y las hiladas del muro de la ciudad eran de todo género de piedras preciosas: la primera, de jaspe; la segunda, de zafiro; la tercera, de calcedonia; la cuarta, de esmeralda; la quinta, de sardónica; la sexta, de cornalina; la séptima, de crisólito; la octava, de berilo; la novena, de topacio; la décima, de crisoprasa; la undécima, de jacinto, y la duodécima, de amatista. Las doce puertas eran doce perlas, cada una de la puertas era de una perla, y la plaza de la ciudad era de oro puro, como vidrio transparente (Nácar/Colunga, 1975).

One of the purposes is certainly a referential-descriptive one. St. John sees the city in a vision and describes what he has seen to his readers. For a reader who is an expert in precious stones (and knows what they were like in a certain period in Palestine), this text is a (technical) description which fulfils a referential-descriptive function. But beside the referential purpose, the author may have had the intention to express his admiration for the beauty of the city he has seen. On the grounds of the assumption that his addressees knew the colours of all the stones he is describing, the author need not mention them explicitly. And if we want the target audience to share the author's admiration of the beauty and colourfulness of his vision, we would have to explicitate what is implicit in the text.

The city wall is made of jasper, and the city itself of gold that is as pure as glass. The foundations of the city wall are of great beauty, for they are built out of precious stones in many different colours. The first foundation-stone is jasper, the second blue sapphire, the third red agate, the fourth light green emerald, the fifth reddish brown onyx, the sixth yellowish red carnelian, the seventh yellow-gold quartz, the eighth beryl as green as the sea, the ninth shining yellow topaz, the tenth chalcedony, shimmering green-golden, the eleventh deep red turquoise, the twelfth purple amethyst. The twelve gates are twelve pearls, each gate is made from a single pearl. The main street of the city is of gold as pure as glass (Berger/Nord, 1999, translated into English). 
But even the expressive purpose may not be the most important one. This vision is presented at the end of last book of our Bible, following the horrors of the apopcalypse. No matter whether it was the intention of the author or of those who composed the canon, the vision of the New Jerusalem seems to be the absolute culmination of the Christian message. We may assume, therefore, that there is also an appellative purpose underlying the text, since it presents the ideal of God's new creation, for which a large number of martyrs through History were prepared to give their lives. An appellative intention cannot be carried out by a technical description - for this purpose, we definitely need to know the colours. Somebody has compared the picture presented by the Berger/Nord translation with a kind of "Disneyland"-too many different colours, too much light. The criticism shows a difference in aesthetic value systems: the critic came from Finland. What is regarded as beautiful in one culture need not be judged the same way in another. Just think of the colourful attire of Latin American indians or Africans! Maybe the love for "loud" colours comes along with hot climates and spicy food. A German girl said she did not find the New Jerusalem very attractive because it seemed so cold to her with all the gold and precious stones. Again, this may be due to a difference in value systems: For Germans, "Gemütlichkeit" (an untranslatable concept denoting warmth and cosiness) is a highly rated value in terms of housing and privacy.

Another appellative element is the comparison: pure gold als clear as glass. Some translations speak of "gold that is transparent as glass". This seems puzzling: How can gold be transparent? There again we have to think of the culture in which the comparison is used. At that time, gold was usually alloyed with other metals, such as copper. Pure gold was as rare and precious as pure glass. The tertium comparationis is not transparency but pureness. Pure gold (like pure glass) is particulary shining in a Palestinian sun.

The example shows that the three functions (referential, expressive, and appellative) are interlinked. If the text is to achieve the intended functions for a central European audience of our time, the translator has to choose the translation strategy carefully. There is no point in adapting the description of the New Jerusalem to the target-culture tastes and value systems, if the rest of the New Testament tells us a story from a strange and distant culture. So it would have to be a type-A translation. However, if the intention is to make the reader understand the appellativity of the message, the strangeness of the source culture has to be made accessible. This is what Berger/Nord call "Otherness Understood" (=Verstandene Fremdheit, cf. Berger/Nord, 1999: 22ff).. In terms of my typology, the translation is an exoticizing translation of the documentary type (cf. Nord, 1997: 49f).

\section{Conclusion}

Functionalism is widely seen as appealing to common sense -although many people think that the field where it is most useful is that of "professional translation" in the sense of translation of computer manuals, operating instructions, technical descriptions, and commercial correspondence. If the source text is no longer regarded as the only yardstick, 
the other pole -the participants and conditions of the target situation-must naturally come more into focus. In ordere to emphasize this change of perspective, functionalists have probably insisted more on cases where adaptive procedures ensure the functionality of the original than on all the other cases where documentary translation forms are called for. This may have produced the impression that functionalist models in general, or Skopostheorie in particular, are mainly models of adaptation. Yet this impression is really no more than a form of "selective reception", a quite normal process whereby, confronted by a large offer of information, we pay attention to only those items that succeed in awaking our interest or our disapproval. As has been shown above, the functional approach accounts for all sorts of both documentary and instrumental modes of translation. To illustrate this point, I have used examples from the translation of Biblical texts, and I hope to have shown that the criteria of functionality can be applied even to this highly sensitive field.

\section{Works Cited}

Berger, Klaus and C. Nord (1999a): Das Neue Testament und frïhchristliche Schriften, neu übersetzt und kommentiert von Klaus Berger und Christiane Nord. Frankfurt/Main: Insel Verlag.

Bühler, Karl (1934): Sprachtheorie. Jena: Fischer.

Catford, J.C. (1965): A Linguistic Theory of Translation, Oxford: Oxford University Press.

Cicero, Marcus Tuillius (46 B.C).: De optimo genere oratorum, English translation by H. M. Hubbell. London: Heinemann, 1959 (= Loeb Classical Library).

DCE: Dictionary of Contemporary English. London: Langenscheidt-Longman.

Dryden, John (1680): "Preface to Ovid's Epistles, Translated by Several Hands", in: Of dramatic poesy, ed. George Watson. London: Dent, 1962.

GNB: Good News Bible (Today's English Version, 1976), publ. by The Bible Societies. Glasgow: Collins.

House, Juliane (1977): A Model for Translation Quality Assessment. Tübingen: Narr.

Jakobson, Roman (1960): "Linguistics and Poetics". In Thomas A. Senbeok, ed., Style in Language. Cambridge Mass.: MIT Press, 350-377.

KJV: The Holy Bible containing the Old and New Testaments (s.a)., transl. out of the original tongues and with the former translations diligently compared and revised by His Majesty's special command, Cambridge: University Press.

Lamadrid, Antonio G. \& Juan Francisco Hernández, Evaristo Martín Nieto, Manuel Revuelta Sañudo (1964): La Santa Biblia, traducida de los textos originales, 18 edición, Madrid: Ediciones Paulinas.

Luther, Martin (1530): "Sendbrief vom Dolmetschen", reproduced in Hans-Joachim Störig (ed) Das Problem des Übersetzens, Darmstadt: Wiss. buchgesellschaft, 1963.

Nácar Fuster, Eloíno \& Alberto Colunga, O.P. (1975): Sagrada Biblia, versión directa de las LENGUAS originales, $4^{a}$ edición ( $1^{a}$ ed. 1970), Madrid: Editorial Católica (= Biblioteca de Autores Cristianos).

Nida, Eurene A. (1964): Toward a Science of Translating. With special reference to principles and procedures involved in Bible translating, Leiden: Brill.

Nord, Christiane (1989): "Loyalität statt Treue: Vorschläge zu einer funktionalen Übersetzungstypologie". Lebende Sprachen 34: 100-105. 
(1997): Translating as a Purposeful Activity. Functionalist Approaches Explained. Manchester: St. Jerome (Translation Theories Explained, 1).

Vermeer, Hans J. (1978): Ein rahmen für eine allgemeine translationstheorie, Nachdruck. In Hans

J. Vermeer (1983): Aufsätze zur Translationstheorie, Heidelberg: Selbstverlag, 48-61. 